\title{
Corrosion Protection and Surface Treatment of Magnesium Alloys Used for Orthopedic Applications
}

\author{
Nabil Nassif and Ibrahim Ghayad \\ Corrosion Control and Surface Protection Department, Central Metallurgical Research and Development Institute (CMRDI), \\ P.O. Box 87, Helwan, Cairo, Egypt
}

Correspondence should be addressed to Ibrahim Ghayad; ighayad@yahoo.com

Received 1 May 2013; Revised 27 June 2013; Accepted 5 July 2013

Academic Editor: Toshihiro Kasuga

Copyright ( 2013 N. Nassif and I. Ghayad. This is an open access article distributed under the Creative Commons Attribution License, which permits unrestricted use, distribution, and reproduction in any medium, provided the original work is properly cited.

\begin{abstract}
An overview is reported about the history of prevailing magnesium alloys as orthopedic biodegradable materials. Important features of the effect of alloying additions, along with surface treatments for corrosion protection of magnesium alloys, are described. Hydroxyapatite (HA), the promising coat deposited by different direct and electrochemical methods to tailor corrosion resistance and biocompatibility, is discussed. Surface modifications, such as microarc oxidation or anodization which lead to nanostructures fabricated to provide better adhesion for HA coatings, are presented.
\end{abstract}

\section{Introduction}

Metallic materials continue to play an essential role as biomaterials to assist with the repair or replacement of bone tissue that has become diseased or damaged [1]. Metals are more suitable for load-bearing applications compared with ceramics or polymeric materials due to their combination of high mechanical strength and fracture toughness. Currently approved and commonly used metallic biomaterials include stainless steels, titanium, and cobalt-chromium-based alloys. A limitation of these current metallic biomaterials is the possible release of toxic metallic ions and/or particles through corrosion or wear processes [2-6] that lead to inflammatory cascades which reduce biocompatibility and cause tissue loss $[2,4-13]$. Moreover, the elastic moduli of these alloys are not well matched with that of natural bone tissue, resulting in stress shielding effects that can lead to reduced stimulation of new bone growth and remodeling which decreases implant stability [14]. Current metallic biomaterials are essentially neutral in vivo, remaining as permanent fixtures, which in the case of plates, screws, and pins used to secure serious fractures must be removed by a second surgical procedure after the tissue has healed sufficiently [15]. Repeat surgery increases costs to the health care system and further morbidity to the patient.

\section{Magnesium Alloys as a Biodegradable Implant Material}

Fortunately, magnesium, $\mathrm{Mg}$, and its alloys which are chemically active can degrade naturally in the physiological environment by corrosion and are potential candidates in biodegradable hard-tissue implants. $\mathrm{Mg}^{2+}$ is the fourth most abundant cation in the human body and is largely stored mainly in bone tissues. It is vital to metabolism processes, a cofactor in many enzymes, and a key component of the ribosomal machinery that translates the genetic information encoded by mRNA into polypeptide structures [16-19]. Early clinical investigations and recent in vivo and in vitro studies suggest that Mg-based implants have good biocompatibility [20-22]. It has also been reported that Mg-based implants can stimulate the development of a hard callous at fracture sites $[20,23]$. The unique mechanical properties of $\mathrm{Mg}$ alloys also render them desirable hard-tissue implants. Mg alloys possess a density of $\approx 1.7-2.0 \mathrm{~g} \mathrm{~cm}^{-3}$ that is close to that of natural bones $\left(1.8-2.1 \mathrm{~g} \mathrm{~cm}^{-3}\right)$, and the compressive strength and tensile strength are much higher than those of biodegradable polymers. Compared with $\mathrm{Ti}$ alloys (110-117 GPa), stainless steels (189-205 GPa), and Co-Cr alloys (230 GPa), the elastic modulus of $\mathrm{Mg}$ alloys (41-45 GPa) is closer to that of natural bones. Hence, the stress shielding effect can be mitigated [16]. 
However, the major drawback of Mg alloys is their low corrosion resistance in the body. In this respect, $\mathrm{Mg}$ is undesirable because it is very active chemically, with a standard potential $\approx-1.7 \mathrm{~V}$ (standard hydrogen potential). The native $\mathrm{MgO}$ and/or $\mathrm{Mg}(\mathrm{OH})_{2}$ surface layers are loose in nature and cannot provide sufficient protection to resist corrosion encountered in the physiological environment which contains a large amount of chloride ions ( $104 \mathrm{mmol} / \mathrm{L})$ [24]. Chloride ions can convert the surface $\mathrm{Mg}(\mathrm{OH})_{2}$ into more soluble $\mathrm{MgCl}_{2}$, and dissolution of $\mathrm{Mg}(\mathrm{OH})_{2}$ makes the surface more active, decreasing the protected area and promoting further dissolution of $\mathrm{Mg}$. The reactions are summarized as follows [16, 24]:

$$
\begin{gathered}
\mathrm{Mg}+2 \mathrm{Cl}^{-} \longrightarrow \mathrm{MgCl}_{2} \\
\mathrm{Mg}(\mathrm{OH})_{2}+2 \mathrm{Cl}^{-} \longrightarrow \mathrm{MgCl}_{2}
\end{gathered}
$$

In addition, the high concentration of buffering agents in the body plasma is responsible for the high dissolution rate of $\mathrm{Mg}$. When $\mathrm{Mg}$ is exposed to an aqueous solution, the following reaction takes place [24]:

$$
\mathrm{Mg}+2 \mathrm{H}_{2} \mathrm{O} \longrightarrow \mathrm{Mg}^{2+}+2 \mathrm{OH}^{-}+\mathrm{H}_{2}
$$

The buffering agents consume the generated $\mathrm{OH}^{-}$quickly in turn, expediting the conversion from $\mathrm{Mg}$ to $\mathrm{Mg}^{2+}$. It has been demonstrated that inorganic components as well as proteins and amino acids influence the degradation rate. As a result, $\mathrm{Mg}$-based biomedical implants can lose the necessary mechanical integrity before the tissue has sufficient time to heal completely. Hard-tissue repair typically requires implantation of the fixture for at least 12 weeks [16].

\section{Corrosion Protection of Mg Alloys}

Improvement of corrosion resistance of $\mathrm{Mg}$ alloys could be achieved via alloying [22, 25], use of composites [26], or surface treatment.

3.1. Effect of Alloying Elements. An appropriate alloying composition can improve the corrosion resistance, mechanical properties, and the ease of manufacture of Mg-based materials. Two primary groups of $\mathrm{Mg}$-based alloys are those contain $2-10 \mathrm{wt} \%$ aluminum (Al) with trace additions of zinc ( $\mathrm{Zn})$ and manganese $(\mathrm{Mn})$, demonstrate moderate corrosion resistance and improved mechanical properties [27]. The second group uses a mixture of rare earth (RE) elements in combination with another metal such as zinc, yttrium, or sliver and a small amount of zirconium which imparts a fine grain structure and enhanced mechanical properties [27]. As these materials are used in the body, care must be taken to choose alloying elements that are nontoxic. However, it is well known that Al is harmful to neurons [28] and osteoblasts [29] and is also associated with dementia and Alzheimer's disease [28]. The administration of RE ( $\mathrm{Pr}, \mathrm{Ce}, \mathrm{Y}$, etc.) could lead to hepatotoxicity [30]. Excessive Yttrium ions $\left(\mathrm{Y}^{+3}\right)$ have been shown to change the expression of some rat genes and to have adverse effects on DNA transcription factors [31]. This has led to a demand for the development of a novel biodegradable $\mathrm{Mg}$ alloys in which $\mathrm{Ca}, \mathrm{Zn}, \mathrm{Mn}$, and $\mathrm{Si}$ could be an appropriate alloying elements, such as:

$$
\begin{aligned}
& \operatorname{Mg}-x \mathrm{Ca}(x=1,2,3,4,5 \cdots) \text { [32-34], } \\
& \text { Mg-1Zn-1Ca [35], } \\
& \text { Mg-2Zn-1.2Mn-1Ca [36], } \\
& \text { Mg-Si }(-\mathrm{Ca}, \mathrm{Zn)}[37], \\
& \operatorname{Mg}-x \mathrm{Zn}(x=1,3,6,10)[32,38-40] \\
& \operatorname{Mg}-1 \mathrm{Mn}-1 \mathrm{Zn}[41], \\
& \operatorname{Mg}-1 \mathrm{Mn}[32] .
\end{aligned}
$$

$\mathrm{Ca}$ or $\mathrm{Zn}$ is one of the most abundant nutritionally essential elements in the human body [34, 37, 42-45] and has basic safety for biomedical applications. $\mathrm{Mn}$ is an essential trace element $(<0.8 \mathrm{mg} / \mathrm{L}$ in blood serum), but high concentration may induce neurotoxicity [46]. Zn and/or Mn helps to overcome the harmful corrosion effect of iron $(\mathrm{Fe})$ and nickel $(\mathrm{Ni})$ impurities that might be present in $\mathrm{Mg}$ alloys. Ca reduces oxidation in the molten condition and during heat treatment. It also improves the rollability [47]. $\mathrm{Mg}-1 \mathrm{Zn}$ produced less hydrogen than many other binary $\mathrm{Mg}$ alloys in simulated body fluid (SBF) [48]. Ca and $\mathrm{Zn}$ act as grain refining agents which improve both corrosion resistance and mechanical properties $[49,50]$. With increasing Ca content, more and coarser $\mathrm{Mg}_{2} \mathrm{Ca}$ phase precipitates are along grain boundaries, weakening both the mechanical property and corrosion resistance of as-cast Mg-Ca alloy [51]. An as-extruded Mg-4Zn0.2Ca ternary alloy [52] exhibited excellent mechanical integrity during in vitro degradation. After 30 days immersion in simulated body fluid (SBF) solutions, the values of the yield strength, the ultimate tensile strength, the elongation, and the elastic modulus of the alloy were degraded to values which still enough for bone fixing [52]. Ca ion concentration up to $50 \mathrm{mg} / \mathrm{L}, \mathrm{Zn}$ ion concentration up to $60 \mathrm{mg} / \mathrm{L}$, and $\mathrm{Mg}$ ion concentration up to $1000 \mathrm{mg} / \mathrm{L}$ did not cause cell toxicity [37].

Strontium (Sr), along with $\mathrm{Ca}$ and $\mathrm{Mg}$, shares similar chemical, biological, and metallurgical properties. There is about $140 \mathrm{mg} \mathrm{Sr}$ in the human body, and 99\% of the body content of $\mathrm{Sr}$ is located in the bones. Proper addition of $\mathrm{Sr}$ can refine the grain size of $\mathrm{Mg}$ alloys and enhance the corrosion resistance. Gu et al. [53] prepared hot rolled $\mathrm{Mg}-\mathrm{Sr}$ binary alloys with a Sr content ranging from 1 to $4 \mathrm{wt} \%$ and found that $\mathrm{Mg}-2 \mathrm{Sr}$ alloy exhibited the highest strength and the lowest corrosion rate. The in vivo results showed that the degrading as-rolled $\mathrm{Mg}$-2Sr alloy promoted bone mineralization and peri-implant new bone formation without inducing any significant adverse effects [54]. Ternary alloys, $\mathrm{Mg}-\mathrm{Zn}-\mathrm{Sr}$ [54], and Mg-Ca-Sr [55] were also developed, both of which suggest that the presence of higher amount of secondary intermetallic phases leads to poorer corrosion resistance.

Silicon $(\mathrm{Si})$ has been regarded recently as an essential mineral in the human body [56]. It plays an important role in aiding the healing process and helping to build the immune system [57]. Moreover, it may be important for the growth and development of bone and connective tissue [58]. Therefore, it is also possible for $\mathrm{Mg}$-Si alloy to be a biodegradable bone implant material. Refinement of microstructure by $\mathrm{Ca}$ 
is an effective way to improve mechanical and corrosion properties $[49,50]$. It is worthy to note that heat treatment of these $\mathrm{Mg}$ alloys can improve both mechanical and corrosion properties $[59,60]$.

3.2. Surface Treatments of Mg Alloys. Surface treatment of Mg alloys is of particular interest for degradable implants because the corrosion rate is intended to be low in the initial phase due to the modified surface layer and then returns to the normal value when the layer corrodes away. Such a degradation pattern is desirable since the loss of strength of the implant would mirror the increase in strength of the healing union by providing sufficient support in the initial phase [61]. A large body of methods in the surface treatment of $\mathrm{Mg}$ alloys for improving corrosion resistance has been reported in the literature [62]. However, these methods are intended for industrial applications and might contain materials that are toxic. For implant applications, several approaches have also been reported to optimize and tailor the corrosion behavior as well as the biocompatibility.

3.2.1. Hydroxyapatite (HA) Coatings. For orthopedic applications, hydroxyapatite (HA) $[25,26,43,63-70]$ or other types of calcium phosphate (Ca-P) coatings are generally of high interest. Generally, the corrosion rate of $\mathrm{Mg}$ alloys is significantly decreased by different types of Ca-P coatings. As the detailed nature of the coatings studied varies over a wide range, of course also the measured degradation rates are different. From the preparation point of view, the most simple are Ca-P coatings that spontaneously form on $\mathrm{Mg}$ and $\mathrm{Mg}$ alloys upon exposure to simulated biofluids [71-74]. In addition to influencing the corrosion rate of $\mathrm{Mg}$, Ca-P coating has been shown to be beneficial for biocompatibility $[75,76]$. The layer that forms spontaneously on $\mathrm{Mg}$ alloys in SBF solution is not hydroxyapatite but instead an amorphous mixed $(\mathrm{Mg}$, $\mathrm{Ca}$-phosphate (which can be carbonated and hydrated).

HA $\left[\left(\mathrm{Ca}_{10}\left(\mathrm{PO}_{4}\right)_{6}(\mathrm{OH})_{2}\right)\right]$ is currently used as a biomedical material due to its excellent biocompatibility and bioactivity, attributed to its chemical and structural similarities to bone and tooth minerals [77]. On account of its low strength and high brittleness, an important use of HA is as a bioactive coating on metallic substrates. Many methods have already been developed to prepare HA coatings on metallic substrates, such as sol-gel process [78], electrophoretic deposition [79], sputtering process [80], laser surface melting [81], pulse laser deposition [82], physical vapor deposition (PVD) [83], plasma spraying [84], and biomimetic methods [85]. However, these cannot be used to deposit HA coating on $\mathrm{Mg}$ alloys because of its low melting point and poor heat resistance. It is well established that HA deposited from aqueous solution has a composition and structure more close to that of human bones and teeth $[66,68,86]$. Thus, chemical or electrochemical method $[63,73-77,87,88]$ is the proper way to prepare HA coating on $\mathrm{Mg}$ substrates.

Certainly, a single-step coating process using nontoxic aqueous solution without applying electrical current is the most preferable from the view point of product cost and environmental load. However, this direct synthesis of HA [66-68] on $\mathrm{Mg}$ alloys was, and still now, a scientific challenge because
$\mathrm{Mg}$ ions prevent HA crystallization with the substitution of $\mathrm{Mg}$ atom for the $\mathrm{Ca}$ atom in the HA structure. Subsequently, the HA structure is destabilized by a decrease in the atomic ratio of $\mathrm{Ca} / \mathrm{P}$; that is, $\mathrm{Mg}$ ions inhibit apatite nucleation and growth. However, calcium-phosphate apatites were detected on alkali and heat treated $\mathrm{Mg}$ after they had been soaked in SBF for 14 days [68]. Direct HA coating was successfully carried out on $\mathrm{Mg}$ alloys in aqueous solution by Hiromoto and Yamamoto [74], but the coating time is up to $24 \mathrm{~h}$. An electroless method to prepare a stable HA-containing conversion coating on $\mathrm{Mg}$ was also reported [89]. The utility of an equilibrium diagram generated by the use of advanced software allowed for the conversion coating solution concentration and $\mathrm{pH}$ to be selected to optimize coating preparation, which was specifically Ca-deficient $\mathrm{HA}-\mathrm{Mg}(\mathrm{OH})_{2}$. To overcome $\mathrm{Mg}$ ions inhibition just mentioned, one approach uses optimized solution chemistry to produce poorly crystalline HA on Mg alloy AZ31 [90]. Another approach uses Ca-chelate compound $[74,91]$ and optimized solution chemistry and temperature to obtain dense and uniform HA coatings, on pure $\mathrm{Mg}$, that takes less than 2 hours [91].

Electrochemical deposition (ED) of $\mathrm{HA}$ on $\mathrm{Mg}$ alloys also has unique advantages due to its capability of forming a uniform coating on a porous substrate or one with a complex shape, its controllability with regard to the thickness and chemical composition of the coating, and its low deposition temperature $[63,69]$. It is thus recognized as one of the most promising techniques for degradable $\mathrm{Mg}$ alloys.

Nevertheless, in a traditional cathodic electrodeposition process, when a static potential is applied, loose, porous, and low adhesive coatings can easily develop. The main reasons are: first, a polarization in concentrations is formed, since the speed of ion diffusion from the main body of the solution to the surface of the metallic substrate is too slow, and secondly, $\mathrm{H}_{2}$ is produced on the cathode due to the reduction of $\mathrm{H}_{2} \mathrm{O}$. To solve this problem, it is suggested that pulsed power (pulse reverse current, PRC) be used for depositing the adherent coating [92-95]. The PRC parameters are demonstrated in [35].

Pure HA coating suffers relatively high dissolution rate in the biological environment [95], which is unfavorable for long-term stability of the implant and makes the interface between bone and implant unstable $[96,97]$. Recently, many researchers have focused on the application of fluorinedoped hydroxyapatite $\mathrm{Ca}_{10}(\mathrm{PO} 4)_{6}(\mathrm{OH})_{2-x} \mathrm{~F}_{x}(\mathrm{FHA})$ as a bioactive coating to provide early stability and long-term performance $[98,99]$. In comparison with pure HA coating, FHA coating could provide significant dissolution-resistant property, better apatite-like layer deposition, better protein adsorption, better cell attachment, and improved alkaline phosphataze activity in cell culture $[98,100]$. Since FHA and $\mathrm{Mg}$ alloy are all degradable, Mg alloy with FHA coating has received more and more interest as biodegradable materials $[66,100]$. Pulse reverse current (PRC) technique was also used to deposit FHA coating on $\mathrm{Mg}$ alloys [35]. Besides, $\mathrm{H}_{2} \mathrm{O}_{2}$, a strong oxidative reagent, was introduced into the electrolyte, which was first induced on cathode to only produce $\mathrm{OH}^{-}$ions during the electrodeposition process [101]. Therefore, $\mathrm{H}_{2} \mathrm{O}_{2}$ could reduce the effect of $\mathrm{H}_{2}$ evolution on 
the nucleation and growth of nano-FHA coating by PRC technique.

Microarc oxidation (MAO) [67, 102-106] followed by electrochemical deposition (ED) of HA is another attempt to overcome the single HA coating obtained through ED which has a low bonding $[107,108]$ strength (about 4-6 MPa) and may lead to peel off after implantation [107]. MAO, which is an electrolytic process, can fabricate porous ceramic coating with high adhesion to the substrate. It is outlined that this porous coating can be used as the intermediate layer for depositing HA because it can generate pinning force when HA is deposited in the pores [109] and enhance the corrosion resistance of the porous layer. At the same time, recent developments in biomineralization have already demonstrated that nanosized crystals and particles play an important role in the formation of hard tissues of animals [110]. As reported in [111, 112], mechanical properties, such as compressive strength, hardness, and indentation fracture toughness, of HA increased with a decrease in grain size, and the nanosized HA can promote bone cell adhesion and proliferation in comparison with microsized HA [111, 113]. Therefore fabricating a nanosized HA coating on the MAO coating may be a promising way to improve the biocompatibility and corrosion resistance of $\mathrm{Mg}$ alloys. The MAO coating is prepared under a pulse voltage mode, and the cell potential is increased gradually till $165-175 \mathrm{~V}$; then the working electrode is oxidized for about $30 \mathrm{~min}$. [67]. The electrolyte is prepared by dissolving $0.1 \mathrm{~mol} / \mathrm{L} \mathrm{Na} \mathrm{PO}_{4} \cdot 12 \mathrm{H}_{2} \mathrm{O}$, $0.028 \mathrm{~mol} / \mathrm{L} \mathrm{CH}{ }_{14} \mathrm{~N}_{2} \mathrm{Na}_{2} \mathrm{O}_{8} \cdot \mathrm{H}_{2} \mathrm{O}, 0.01 \mathrm{~mol} / \mathrm{L} \mathrm{Na}_{2} \mathrm{SiO}_{3} \cdot 9 \mathrm{H}_{2} \mathrm{O}$, and $0.28 \mathrm{~mol} / \mathrm{L} \mathrm{KF} \cdot 2 \mathrm{H}_{2} \mathrm{O}$ in distilled water. According to another publication [104], MAO was conducted at a fixed applied voltage in the range $360-400 \mathrm{~V}$ for $10 \mathrm{~min}$ to obtain promising results for the surface treatment of $\mathrm{Mg}$-Ca alloys which exhibit good corrosion resistance and surface biocompatibility. The electrolyte was prepared from the solution of $10 \mathrm{~g} / \mathrm{L}$ sodium silicate with $3.5 \mathrm{~g} / \mathrm{L}$ sodium hydroxide. Shi et al. [106] performed $\mathrm{MAO}$ in $500 \mathrm{~mL}$ aqueous solution containing $50 \mathrm{~g} / \mathrm{L} \mathrm{NaOH}, 40 \mathrm{~g} / \mathrm{L} \mathrm{Na}_{2} \mathrm{SiO}_{3}, 20 \mathrm{~g} / \mathrm{L} \mathrm{Na}_{2} \mathrm{~B}_{4} \mathrm{O}_{7}$, and $40 \mathrm{~g} / \mathrm{L} \mathrm{Na}_{3} \mathrm{C}_{6} \mathrm{H}_{5} \mathrm{O}_{7}$ at a constant potential of $90 \mathrm{~V}$ for $40 \mathrm{~min}$.

Anodization is the third type of techniques to fabricate nanostructure coatings. It is also an electrolytic oxidation process in which the metal as anode is converted to oxide film having desirable corrosion protective, decorative, and functional properties [114-120]. Anodization can increase the film thickness, hardness, corrosion resistance, and wear resistance and provide better adhesion for primers than the bare metal. The anodizing behavior of $\mathrm{Mg}$ alloys is strongly influenced by the voltage or current applied. Different passive and active states can be found depending on the applied voltage/current, time, substrate, and electrolyte [121]. Studies have investigated many aspects of anodizing $\mathrm{Mg}$, such as electrolyte composition [122-125], anodizing parameters such as constant voltage or constant current density control modes [120,124,126], substrate effects including substrate type, $\mathrm{Mg}$ purity, and alloying element concentration $[38,72,120,124,127]$, and time of anodization [114]. Different electrolytes have been proposed: either an aqueous [114-116, 123-125, 128-132] or nonaqueous $[119,133]$ solutions. However, when anodization is used in the bioenvironment, there are certain requirements for the coating. The coating should be thick, strong, and nontoxic. That is to say electrolyte should be carefully designed.

Over the past decades, a variety of self-ordering electrochemical processes have been found to produce oxide nanostructures from aqueous or nonaqueous fluoride-containing solutions [134]. Under optimized conditions resulting surface features are regular tubular (nanotubular) or porous structures. There are many works reported in the literature on the formation of ordered porous oxides of metals including valve metals, such as Al [135, 136], Ta [137], $\operatorname{Zr}[138,139]$, $\mathrm{Nb}$ [140, 141], Ti [142-144], and Hf [145], but only a few attempts can be found based on $\mathrm{Mg}$ and $\mathrm{Mg}$ alloys. Since $\mathrm{Mg}$ hardly forms defined oxide films in aqueous solution, it may be a promising approach to use nonaqueous solutions for anodization, particularly with the aim of reducing chemical dissolution during anodization. Brunner et al. [133] showed the formation of a black, porous oxide layer on $\mathrm{Mg}$ from water free methanol or ethanol electrolytes containing nitrate ions. Ono and Asoh [146] studied anodization of pure $\mathrm{Mg}$ in nonaqueous solutions where they showed the formation of a barrier layer in a solution consisting of a mixture of amine, ethylene glycol, and water. They also investigated the formation of anodic oxide films on $\mathrm{Mg}$ surfaces in alkalinefluoride solutions [125] and for the first time, using alkaline aluminate solution, they reported formation of cylindrical cellular structures [124].

In order to optimize the biological performance, the corrosion behavior of the material as well as its interactions with cells needs to be tailored. For instance, in the case of $\mathrm{Ti}$, drastic influence of nanotubular $\mathrm{TiO}_{2}$ layers on the cell behavior has been reported as compared with compact $\mathrm{TiO}_{2}$ layers [147]. Moreover, such nanotubular surface layers were found to enhance the formation of HA on the Ti surface [148]. In the case of $\mathrm{Mg}$, electrochemical anodization approaches to achieve similar surface morphologies as reported for Ti have been explored, and even though nanoporous [133] as well as nanotubular [119] surface layer has been reported. These nanostructures until now show a poor order. Moreover, possible enhancement of biological functionalities by such nanostructured surface layer has not yet been explored.

3.2.2. Miscellaneous Coating Approaches. Apart from the above mentioned $\mathrm{Ca}-\mathrm{P}$ coatings, many coating techniques have been developed to reduce the corrosion of $\mathrm{Mg}$ alloys, such as hydrogenated amorphous silicon [149], alkaline heat treatment $[68,150]$, carbonate treatment [151], fluoride conversion coatings [152-157], biodegradable polymers [158$160]$, or composite coatings of polymers and calcium phosphates [161-163]. Moreover, the degradation behavior of $\mathrm{Mg}$ alloys can be significantly influenced by self-assembled monolayers $[164,165]$ or by protein adsorption layers which can be covalently bound to Mg surface using silane coupling chemistry [166]. The latter approach may have the advantage that in addition to the demonstrated strong effects on $\mathrm{Mg}$ dissolution rate, binding of specific proteins on the surface prevents nonspecific adsorption from the body fluids and hence may offer a wide range of possibilities to tailor the biological performance to match the requirements of the specific application targeted. 
Fluoride chemical conversion coatings own merits such as low cost and simplicity in operation [167]. Fluoride is one of the few known agents that can stimulate osteoblast proliferation and increase new mineral deposition in cancellous bones. It is essential in the diet of human beings and is thought to be required for normal dental and skeletal growths [168]. Fluoride incorporated into the bone increases the size and, thus, decreases the solubility of the bone apatite crystals [169].

\section{Concluding Remarks}

The key to develop Mg-based alloys that are suitable as biodegradable orthopedic implants is how to control their degradation rates and mechanical integrity in the physiological environment $[35,153]$. That is to say, $\mathrm{Mg}$ alloys would remain in the body and maintain mechanical integrity over a time period of 6-12 weeks for upper limbs or 12-24 weeks for lower limbs [170, 171], 12-18 weeks [35], 12 weeks [45], or three phases: 3-7 days, 3-4 months, and months to years $[170,172]$, while the bone tissue heals, eventually are replaced by natural tissue. It is also important that the degradation products, such as, $\mathrm{Mg}^{2+}, \mathrm{H}_{2}$, and $\mathrm{OH}^{-}$should be within the body's acceptable absorption levels [35]. If $\mathrm{pH}$ change and $\mathrm{H}_{2}$ evolution increase are too drastic, cell death [118] and spalling off the coat as well as susceptibility to stress corrosion cracking and $\mathrm{H}_{2}$-embrittlement $[173,174]$ of the implant material can take place. However, if the corrosion rate of Mg-implant can be controlled by developing novel alloys or surface modifications, the biological environment may be better able to deal with $\mathrm{H}_{2}$-gas and $\mathrm{OH}^{-}$ions generation.

\section{Conflict of Interests}

The authors hereby certify that there are no financial or competing interests that exist in this work.

\section{References}

[1] M. Niinomi, "Recent metallic materials for biomedical applications," Metallurgical and Materials Transactions A, vol. 33, pp. 477-486, 2002.

[2] D. A. Puleo and W. W. Huh, "Acute toxicity of metal ions in cultures of osteogenic cells derived from bone marrow stromal cells," Journal of Applied Biomaterials, vol. 6, no. 2, pp. 109-116, 1995.

[3] J. J. Jacobs, J. L. Gilbert, and R. M. Urban, "Corrosion of metal orthopaedic implants," Journal of Bone and Joint Surgery A, vol. 80, no. 2, pp. 268-282, 1998.

[4] C. Lhotka, T. Szekeres, I. Steffan, K. Zhuber, and K. Zweymüller, "Four-year study of cobalt and chromium blood levels in patients managed with two different metal-on-metal total hip replacements," Journal of Orthopaedic Research, vol. 21, no. 2, pp. 189-195, 2003.

[5] J. J. Jacobs, A. K. Skipor, L. M. Patterson et al., "Metal release in patients who have had a primary total hip arthroplasty: a prospective, controlled, longitudinal study," Journal of Bone and Joint Surgery A, vol. 80, no. 10, pp. 1447-1458, 1998.

[6] J. J. Jacobs, N. J. Hallab, A. K. Skipor, and R. M. Urban, "Metal degradation products: a cause for concern in metal-metal bearings?" Clinical Orthopaedics and Related Research, no. 417, pp. 139-147, 2003.

[7] D. Granchi, G. Ciapetti, S. Stea et al., "Cytokine release in mononuclear cells of patients with Co-Cr hip prosthesis," Biomaterials, vol. 20, no. 12, pp. 1079-1086, 1999.

[8] Y. Niki, H. Matsumoto, Y. Suda et al., "Metal ions induce boneresorbing cytokine production through the redox pathway in synoviocytes and bone marrow macrophages," Biomaterials, vol. 24, no. 8, pp. 1447-1457, 2003.

[9] D. R. Haynes, S. J. Boyle, S. D. Rogers, D. W. Howie, and B. Vernon-Roberts, "Variation in cytokines induced by particles from different prosthetic materials," Clinical Orthopaedics and Related Research, no. 352, pp. 223-230, 1998.

[10] J. Y. Wang, B. H. Wicklund, R. B. Gustilo, and D. T. Tsukayama, "Titanium, chromium and cobalt ions modulate the release of bone-associated cytokines by human monocytes/macrophages in vitro," Biomaterials, vol. 17, no. 23, pp. 2233-2240, 1996.

[11] B. I. Yanming, R. R. Van De Motter, A. A. Ragab, V. M. Goldberg, J. M. Anderson, and E. M. Greenfield, "Titanium particles stimulate bone resorption by inducing differentiation of murine osteoclasts," Journal of Bone and Joint Surgery A, vol. 83, no. 4, pp. 501-508, 2001.

[12] M. J. Allen, B. J. Myer, P. J. Millett, and N. Rushton, “The effects of particulate cobalt, chromium and cobalt-chromium alloy on human osteoblast-like cells in vitro," Journal of Bone and Joint Surgery B, vol. 79, no. 3, pp. 475-482, 1997.

[13] M. L. Wang, L. J. Nesti, R. Tuli et al., “Titanium particles suppress expression of osteoblastic phenotype in human mesenchymal stem cells," Journal of Orthopaedic Research, vol. 20, no. 6, pp. 1175-1184, 2002.

[14] J. Nagels, M. Stokdijk, and P. M. Rozing, "Stress shielding and bone resorption in shoulder arthroplasty," Journal of Shoulder and Elbow Surgery, vol. 12, no. 1, pp. 35-39, 2003.

[15] J. B. Park and Y. K. Kim, "Metallic biomaterial," in Biomaterials Principles and Application, J. B. Park and J. D. Bronzino, Eds., CRC Press, Boca Raton, Fla, USA, 2003.

[16] M. P. Staiger, A. M. Pietak, J. Huadmai, and G. Dias, "Magnesium and its alloys as orthopedic biomaterials: a review," Biomaterials, vol. 27, no. 9, pp. 1728-1734, 2006.

[17] A. Hartwig, "Role of magnesium in genomic stability," Mutation Research, vol. 475, no. 1-2, pp. 113-121, 2001.

[18] F. I. Wolf and A. Cittadini, "Chemistry and biochemistry of magnesium," Molecular Aspects of Medicine, vol. 24, no. 1-3, pp. 3-9, 2003.

[19] J. Vormann, "Magnesium: nutrition and metabolism," Molecular Aspects of Medicine, vol. 24, no. 1-3, pp. 27-37, 2003.

[20] V. V. Troitskii and D. N. Tsitrin, "The resorbing metallic alloy "Osteosintezit" as material for fastening broken bone," Khirurgiia, vol. 8, pp. 41-44, 1944.

[21] E. D. McBride, "Absorbable metal in bone surgery. A further report on the use of magnesium alloys," Journal of the American Medical Association, vol. 111, pp. 2464-2467, 1938.

[22] F. Witte, V. Kaese, H. Haferkamp et al., "In vivo corrosion of four magnesium alloys and the associated bone response," Biomaterials, vol. 26, no. 17, pp. 3557-3563, 2005.

[23] R. Zeng, W. Dietzel, F. Witte, N. Hort, and C. Blawert, "Progress and challenge for magnesium alloys as biomaterials," Advanced Engineering Materials, vol. 10, no. 8, pp. B3-B14, 2008.

[24] G. Song and A. Atrens, "Understanding magnesium corrosion. A framework for improved alloy performance," Advanced Engineering Materials, vol. 5, no. 12, pp. 837-858, 2003. 
[25] F. Witte, J. Fischer, J. Nellesen et al., "In vitro and in vivo corrosion measurements of magnesium alloys," Biomaterials, vol. 27, no. 7, pp. 1013-1018, 2006.

[26] F. Witte, F. Feyerabend, P. Maier et al., "Biodegradable magnesium-hydroxyapatite metal matrix composites," Biomaterials, vol. 28, no. 13, pp. 2163-2174, 2007.

[27] B. A. Shaw, "Corrosion resistance of magnesium alloys," in ASM Handbook, D. Stephen, Ed., vol. 13A of Corrosion: Fundamentals, Testing and Protection, ASM International, London, UK, 2003.

[28] S. S. A. El-Rahman, "Neuropathology of aluminum toxicity in rats (glutamate and GABA impairment)," Pharmacological Research, vol. 47, no. 3, pp. 189-194, 2003.

[29] C.-H. Ku, D. P. Pioletti, M. Browne, and P. J. Gregson, "Effect of different Ti-6Al-4V surface treatments on osteoblasts behaviour," Biomaterials, vol. 23, no. 6, pp. 1447-1454, 2002.

[30] Y. Nakamura, Y. Tsumura, Y. Tonogai, T. Shibata, and Y. Ito, "Differences in behavior among the chlorides of seven rare earth elements administered intravenously to rats," Toxicological Sciences, vol. 37, no. 2, pp. 106-116, 1997.

[31] W. Yang, P. Zhang, J. Liu, and Y. Xue, "Effect of long-term intake of $\mathrm{Y}^{+3}$ in drinking water on gene expression in brains of rats," Journal of Rare Earths, vol. 24, no. 3, pp. 369-373, 2006.

[32] N. T. Kirkland, J. Lespagnol, N. Birbilis, and M. P. Staiger, "A survey of bio-corrosion rates of magnesium alloys," Corrosion Science, vol. 52, no. 2, pp. 287-291, 2010.

[33] W.-C. Kim, J.-G. Kim, J.-Y. Lee, and H.-K. Seok, "Influence of Ca on the corrosion properties of magnesium for biomaterials," Materials Letters, vol. 62, no. 25, pp. 4146-4148, 2008.

[34] Y. Wan, G. Xiong, H. Luo, F. He, Y. Huang, and X. Zhou, "Preparation and characterization of a new biomedical magnesiumcalcium alloy," Materials and Design, vol. 29, no. 10, pp. 20342037, 2008.

[35] H. X. Wang, S. K. Guan, X. Wang, C. X. Ren, and L. G. Wang, "In vitro degradation and mechanical integrity of $\mathrm{Mg}$ Zn-Ca alloy coated with Ca-deficient hydroxyapatite by the pulse electrodeposition process," Acta Biomaterialia, vol. 6, no. 5, pp. 1743-1748, 2010.

[36] E. Zhang and L. Yang, "Microstructure, mechanical properties and bio-corrosion properties of $\mathrm{Mg}-\mathrm{Zn}-\mathrm{Mn}$-Ca alloy for biomedical application," Materials Science and Engineering A, vol. 497, no. 1-2, pp. 111-118, 2008.

[37] E. Zhang, L. Yang, J. Xu, and H. Chen, "Microstructure, mechanical properties and bio-corrosion properties of $\mathrm{Mg}$-Si(-Ca, $\mathrm{Zn}$ ) alloy for biomedical application," Acta Biomaterialia, vol. 6, no. 5, pp. 1756-1762, 2010.

[38] G. Song, "Control of biodegradation of biocompatable magnesium alloys," Corrosion Science, vol. 49, no. 4, pp. 1696-1701, 2007.

[39] L. P. Xu, E. L. Zhang, D. S. Yin, S. Y. Zeng, and K. Yang, "In vitro corrosion behaviour of $\mathrm{Mg}$ alloys in a phosphate buffered solution for bone implant application," Journal of Materials Science, vol. 19, no. 3, pp. 1017-1025, 2008.

[40] S. Zhang, X. Zhang, C. Zhao et al., "Research on an Mg-Zn alloy as a degradable biomaterial," Acta Biomaterialia, vol. 6, no. 2, pp. 626-640, 2010.

[41] L. Yang and E. L. Zhang, "Biocorrosion behavior of magnesium alloy in different simulated fluids for biomedical application," Materials Science and Engineering C, vol. 29, pp. 1691-1696, 2009.
[42] S. Zhang, J. Li, Y. Song et al., "In vitro degradation, hemolysis and MC3T3-E1 cell adhesion of biodegradable Mg-Zn alloy," Materials Science and Engineering C, vol. 29, no. 6, pp. 1907-1912, 2009.

[43] Z. Li, X. Gu, S. Lou, and Y. Zheng, "The development of binary $\mathrm{Mg}-\mathrm{Ca}$ alloys for use as biodegradable materials within bone," Biomaterials, vol. 29, no. 10, pp. 1329-1344, 2008.

[44] H. Tapiero and K. D. Tew, "Trace elements in human physiology and pathology: zinc and metallothioneins," Biomedicine and Pharmacotherapy, vol. 57, no. 9, pp. 399-411, 2003.

[45] Y. Xin, T. Hu, and P. K. Chu, "In vitro studies of biomedical magnesium alloys in a simulated physiological environment: a review," Acta Biomaterialia, vol. 7, no. 4, pp. 1452-1459, 2011.

[46] F. Witte, N. Hort, C. Vogt et al., "Degradable biomaterials based on magnesium corrosion," Current Opinion in Solid State and Materials Science, vol. 12, no. 5-6, pp. 63-72, 2008.

[47] J. Polmear, "Magnesium and magnesium alloys," in ASM Specialty Handbook, M. M. Avedesian and H. Baker, Eds., p. 14, ASM International, Materials Park, Ohio, USA, 1999.

[48] X. Gu, Y. Zheng, Y. Cheng, S. Zhong, and T. Xi, "In vitro corrosion and biocompatibility of binary magnesium alloys," Biomaterials, vol. 30, no. 4, pp. 484-498, 2009.

[49] G. Y. Yuan, Z. L. Liu, Q. D. Wang, and W. J. Ding, "Microstructure refinement of Mg-Al-Zn-Si alloys," Materials Letters, vol. 56, no. 1-2, pp. 53-58, 2002.

[50] A. Srinivasan, S. Ningshen, U. Kamachi Mudali, U. T. S. Pillai, and B. C. Pai, "Influence of Si and Sb additions on the corrosion behavior of AZ91 magnesium alloy," Intermetallics, vol. 15, no. 12, pp. 1511-1517, 2007.

[51] H. R. B. Rad, M. H. Idris, M. R. A. Kadir, and S. Farahany, "Microstructure analysis and corrosion behavior of biodegradable Mg-Ca implant alloys," Materials and Design, vol. 33, no. 1, pp. 88-97, 2012.

[52] Y. Sun, B. Zhang, Y. Wang, L. Geng, and X. Jiao, "Preparation and characterization of a new biomedical Mg-Zn-Ca alloy," Materials and Design, vol. 34, pp. 58-64, 2012.

[53] X. N. Gu, X. H. Xie, N. Li, Y. F. Zheng, and L. Qin, "In vitro and in vivo studies on a Mg-Sr binary alloy system developed as a new kind of biodegradable metal," Acta Biomaterialia, vol. 8, no. 6, pp. 2360-2374, 2012.

[54] H. S. Brar, J. Wong, and M. V. Manuel, "Investigation of the mechanical and degradation properties of $\mathrm{Mg}-\mathrm{Sr}$ and $\mathrm{Mg}-\mathrm{Zn}$ Sr alloys for use as potential biodegradable implant materials," Journal of the Mechanical Behavior of Biomedical Materials, vol. 7, pp. 87-95, 2012.

[55] I. S. Berglund, H. S. Brar, N. Dolgova et al., "Synthesis and characterization of Mg-Ca-Sr alloys for biodegradable orthopedic implant applications," Journal of Biomedical Materials Research $B$, vol. 100, pp. 1524-1534, 2012.

[56] S. E. Whiting, "Not all Minerals Are Created Equal," http://www .healingwithnutrition.com/equalminerals.html.

[57] M. F. McCarty, "Reported antiatherosclerotic activity of silicon may reflect increased endothelial synthesis of heparan sulfate proteoglycans," Medical Hypotheses, vol. 49, no. 2, pp. 175-176, 1997.

[58] S. Sripanyakorn, R. Jugdaohsingh, H. Elliott et al., "The silicon content of beer and its bioavailability in healthy volunteers," British Journal of Nutrition, vol. 91, no. 3, pp. 403-409, 2004.

[59] Z. Xu, C. Smith, S. Chen, and J. Sankar, "Development and microstructural characterizations of $\mathrm{Mg}-\mathrm{Zn}-\mathrm{Ca}$ alloys for biomedical applications," Materials Science and Engineering B, vol. 176, no. 20, pp. 1660-1665, 2011. 
[60] W. Zhou, T. Shen, and N. N. Aung, "Effect of heat treatment on corrosion behaviour of magnesium alloy AZ91D in simulated body fluid," Corrosion Science, vol. 52, no. 3, pp. 1035-1041, 2010.

[61] W. S. Pietrzak, D. Sarver, and M. Verstynen, "Bioresorbable implants-practical considerations," Bone, vol. 19, no. 1, pp. 109S119S, 1996.

[62] J. E. Gray and B. Luan, "Protective coatings on magnesium and its alloys-a critical review," Journal of Alloys and Compounds, vol. 336, no. 1-2, pp. 88-113, 2002.

[63] C. Wen, S. Guan, L. Peng, C. Ren, X. Wang, and Z. Hu, "Characterization and degradation behavior of AZ31 alloy surface modified by bone-like hydroxyapatite for implant applications," Applied Surface Science, vol. 255, no. 13-14, pp. 6433-6438, 2009.

[64] J. D. Majumdar, U. Bhattacharyya, A. Biswas, and I. Manna, "Studies on thermal oxidation of Mg-alloy (AZ91) for improving corrosion and wear resistance," Surface and Coatings Technology, vol. 202, no. 15, pp. 3638-3642, 2008.

[65] L. Xu, G. Yu, E. Zhang, F. Pan, and K. Yang, "In vivo corrosion behavior of Mg-Mn-Zn alloy for bone implant application," Journal of Biomedical Materials Research A, vol. 83, no. 3, pp. 703-711, 2007.

[66] Y. Song, S. Zhang, J. Li, C. Zhao, and X. Zhang, "Electrodeposition of Ca-P coatings on biodegradable $\mathrm{Mg}$ alloy: in vitro biomineralization behavior," Acta Biomaterialia, vol. 6, no. 5, pp. 1736-1742, 2010.

[67] J. H. Gao, S. K. Guan, J. Chen et al., "Fabrication and characterization of rod-like nano-hydroxyapatite on MAO coating supported on Mg-Zn-Ca alloy," Applied Surface Science, vol. 257, no. 6, pp. 2231-2237, 2011.

[68] L. Li, J. Gao, and Y. Wang, "Evaluation of cyto-toxicity and corrosion behavior of alkali-heat-treated magnesium in simulated body fluid," Surface and Coatings Technology, vol. 185, pp. 92-98, 2004.

[69] Y. W. Song, D. Y. Shan, and E. H. Han, "Electrodeposition of hydroxyapatite coating on AZ91D magnesium alloy for biomaterial application," Materials Letters, vol. 62, no. 17-18, pp. 32763279, 2008.

[70] C.-Y. Zhang, R.-C. Zeng, R.-S. Chen, C.-L. Liu, and J.-C. Gao, "Preparation of calcium phosphate coatings on Mg-1.0Ca alloy," Transactions of Nonferrous Metals Society of China, vol. 20, no. 2, pp. s655-s659, 2010.

[71] R. Rettig and S. Virtanen, "Composition of corrosion layers on a magnesium rare-earth alloy in simulated body fluids," Journal of Biomedical Materials Research A, vol. 88, no. 2, pp. 359-369, 2009.

[72] S. Hiromoto, T. Shishido, A. Yamamoto, N. Maruyama, H. Somekawa, and T. Mukai, "Precipitation control of calcium phosphate on pure magnesium by anodization," Corrosion Science, vol. 50, no. 10, pp. 2906-2913, 2008.

[73] D. A. Cortés, H. Y. López, and D. Mantovani, "Spontaneous and biomimetic apatite formation on pure magnesium," Materials Science Forum, vol. 539-543, no. 1, pp. 589-594, 2007.

[74] S. Hiromoto and A. Yamamoto, "High corrosion resistance of magnesium coated with hydroxyapatite directly synthesized in an aqueous solution," Electrochimica Acta, vol. 54, no. 27, pp. 7085-7093, 2009.

[75] F. Geng, L. L. Tan, X. X. Jin, J. Y. Yang, and K. Yang, “The preparation, cytocompatibility, and in vitro biodegradation study of pure $\beta$-TCP on magnesium," Journal of Materials Science, vol. 20, no. 5, pp. 1149-1157, 2009.
[76] L. Xu, F. Pan, G. Yu, L. Yang, E. Zhang, and K. Yang, "In vitro and in vivo evaluation of the surface bioactivity of a calcium phosphate coated magnesium alloy," Biomaterials, vol. 30, no. 8, pp. 1512-1523, 2009.

[77] H. W. Denissen, K. De Groot, P. Ch. Makkes, A. Van Den Hoff, and P. J. Klopper, "Tissue response to dense apatite implants in rats," Journal of Biomedical Materials Research, vol. 14, no. 6, pp. 713-721, 1980.

[78] C. Wu, Y. Ramaswamy, D. Gale et al., "Novel sphene coatings on Ti-6Al-4V for orthopedic implants using sol-gel method," Acta Biomaterialia, vol. 4, no. 3, pp. 569-576, 2008.

[79] M. Javidi, S. Javadpour, M. E. Bahrololoom, and J. Ma, "Electrophoretic deposition of natural hydroxyapatite on medical grade 316L stainless steel," Materials Science and Engineering C, vol. 28, no. 8, pp. 1509-1515, 2008.

[80] Y. Yang, K.-H. Kim, and J. L. Ong, "A review on calcium phosphate coatings produced using a sputtering process-an alternative to plasma spraying," Biomaterials, vol. 26, no. 3, pp. 327337, 2005.

[81] Y. C. Guan, W. Zhou, and H. Y. Zheng, "Effect of laser surface melting on corrosion behaviour of AZ91D Mg alloy in simulated-modified body fluid," Journal of Applied Electrochemistry, vol. 39, pp. 1457-1464, 2009.

[82] F. Garcia, J. L. Arias, B. Mayor et al., "Effect of heat treatment on pulsed laser deposited amorphous calcium phosphate coatings," Journal of Biomedical Materials Research, vol. 43, pp. 69-76, 1998.

[83] S. A. Hacking, M. Zuraw, E. J. Harvey, M. Tanzer, J. J. Krygier, and J. D. Bobyn, "A physical vapor deposition method for controlled evaluation of biological response to biomaterial chemistry and topography," Journal of Biomedical Materials Research A, vol. 82, no. 1, pp. 179-187, 2007.

[84] L.-M. Sun, C. C. Berndt, A. K. Gross, and A. Kucuk, "Material fundamentals and clinical performance of plasma-sprayed hydroxyapatite coatings: a review," Journal of Biomedical Materials Research B, vol. 58, pp. 570-592, 2001.

[85] E. L. Zhang, C. M. Zou, and S. Y. Zeng, "Preparation and characterization of silicon-substituted hydroxyapatite coating by a biomimetic process on titanium substrate," Surface and Coatings Technology, vol. 203, pp. 1075-1080, 2005.

[86] J. M. Zhang, C. J. Lin, Z. D. Feng, and Z. W. Tian, "Mechanistic studies of electrodeposition for bioceramic coatings of calcium phosphates by an in situ $\mathrm{pH}$-microsensor technique," Journal of Electroanalytical Chemistry, vol. 452, no. 2, pp. 235-240, 1998.

[87] Y. Zhang, G. Zhang, and M. Wei, "Controlling the biodegradation rate of magnesium using biomimetic apatite coating," Journal of Biomedical Materials Research B, vol. 89, pp. 408-414, 2008.

[88] Y. Wang, M. Wei, and J. Gao, "Improve corrosion resistance of magnesium in simulated body fluid by dicalcium phosphate dihydrate coating," Materials Science and Engineering C, vol. 29, no. 4, pp. 1311-1316, 2009.

[89] X.-B. Chen, N. Birbilis, and T. B. Abbott, "A simple route towards a hydroxyapatite- $\mathrm{Mg}(\mathrm{OH})_{2}$ conversion coating for magnesium," Corrosion Science, vol. 53, no. 6, pp. 2263-2268, 2011.

[90] J. E. Gray-Munro and M. Strong, “The mechanism of deposition of calcium phosphate coatings from solution onto magnesium alloy AZ31," Journal of Biomedical Materials Research A, vol. 90, pp. 339-350, 2009. 
[91] M. Tomozawa, S. Hiromoto, and Y. Harada, "Microstructure of hydroxyapatite-coated magnesium prepared in aqueous solution," Surface and Coatings Technology, vol. 204, no. 20, pp. 3243-3247, 2010.

[92] M. S. Chandrasekar and M. Pushpavanam, "Pulse and pulse reverse plating-Conceptual, advantages and applications," Electrochimica Acta, vol. 53, no. 8, pp. 3313-3322, 2008.

[93] P. Peng, S. Kumar, N. H. Voelcker, E. Szili, R. S. C. Smart, and H. J. Griesser, "Thin calcium phosphate coatings on titanium by electrochemical deposition in modified simulated body fluid," Journal of Biomedical Materials Research A, vol. 76, no. 2, pp. 347-355, 2006.

[94] S. Lin, R. Z. LeGeros, and J. P. LeGeros, "Adherent octacalciumphosphate coating on titanium alloy using modulated electrochemical deposition method," Journal of Biomedical Materials Research A, vol. 66, no. 4, pp. 819-828, 2003.

[95] E. C. Meng, S. K. Guan, H. X. Wang et al., "Effect of electrodeposition modes on surface characteristics and corrosion properties of fluorine-doped hydroxyapatite coatings on $\mathrm{Mg}-\mathrm{Zn}$-Ca alloy," Applied Surface Science, vol. 257, no. 11, pp. 4811-4816, 2011.

[96] K. Cheng, W. Weng, H. Wang, and S. Zhang, "In vitro behavior of osteoblast-like cells on fluoridated hydroxyapatite coatings," Biomaterials, vol. 26, no. 32, pp. 6288-6295, 2005.

[97] J. Wang, C. Huang, Q. Wan, Y. Chen, and Y. Chao, "Characterization of fluoridated hydroxyapatite/zirconia nano-composite coating deposited by a modified electrocodeposition technique," Surface and Coatings Technology, vol. 204, no. 16-17, pp. 2576-2582, 2010

[98] J. Wang, Y. Chao, Q. Wan, Z. Zhu, and H. Yu, "Fluoridated hydroxyapatite coatings on titanium obtained by electrochemical deposition," Acta Biomaterialia, vol. 5, no. 5, pp. 1798-1807, 2009.

[99] Y. Wang, S. Z. Sam Zhang, X. Zeng, K. C. Kui Cheng, M. Q. Min Qian, and W. Weng, "In vitro behavior of fluoridated hydroxyapatite coatings in organic-containing simulated body fluid," Materials Science and Engineering C, vol. 27, no. 2, pp. 244-250, 2007.

[100] J. Li, Y. Song, S. Zhang et al., "In vitro responses of human bone marrow stromal cells to a fluoridated hydroxyapatite coated biodegradable Mg-Zn alloy," Biomaterials, vol. 31, no. 22, pp. 5782-5788, 2010.

[101] X. Y. Chen, Z. W. Zhao, A. L. Chen, and H. G. Li, "Pulsed electrodeposition of hydroxyapatite on titanium substrate in solution containing hydrogen peroxide," Transactions of Nonferrous Metals Society of China, vol. 17, no. 3, pp. 617-621, 2007.

[102] X. P. Zhang, Z. P. Zhao, F. M. Wu, Y. L. Wang, and J. Wu, "Corrosion and wear resistance of AZ91D magnesium alloy with and without microarc oxidation coating in Hank's solution," Journal of Materials Science, vol. 42, no. 20, pp. 8523-8528, 2007.

[103] Z. Yao, L. Li, and Z. Jiang, "Adjustment of the ratio of Ca/P in the ceramic coating on Mg alloy by plasma electrolytic oxidation," Applied Surface Science, vol. 255, no. 13-14, pp. 6724-6728, 2009.

[104] X. N. Gu, N. Li, W. R. Zhou et al., "Corrosion resistance and surface biocompatibility of a microarc oxidation coating on a Mg-Ca alloy," Acta Biomaterialia, vol. 7, no. 4, pp. 1880-1889, 2011.

[105] J. Liang, P. B. Srinivasan, C. Blawert, and W. Dietzel, "Influence of $\mathrm{pH}$ on the deterioration of plasma electrolytic oxidation coated AM50 magnesium alloy in $\mathrm{NaCl}$ solutions," Corrosion Science, vol. 52, no. 2, pp. 540-547, 2010.
[106] Y. Shi, M. Qi, Y. Chen, and P. Shi, "MAO-DCPD composite coating on $\mathrm{Mg}$ alloy for degradable implant applications," Materials Letters, vol. 65, no. 14, pp. 2201-2204, 2011.

[107] W. Shang, B. Chen, X. Shi, Y. Chen, and X. Xiao, "Electrochemical corrosion behavior of composite $\mathrm{MAO} /$ sol-gel coatings on magnesium alloy AZ91D using combined micro-arc oxidation and sol-gel technique," Journal of Alloys and Compounds, vol. 474, no. 1-2, pp. 541-545, 2009.

[108] S. Ban and J. Hasegawa, "Morphological regulation and crystal growth of hydrothermal-electrochemically deposited apatite," Biomaterials, vol. 23, no. 14, pp. 2965-2972, 2002.

[109] H. Duan, K. Du, C. Yan, and F. Wang, "Electrochemical corrosion behavior of composite coatings of sealed MAO film on magnesium alloy AZ91D," Electrochimica Acta, vol. 51, no. 14, pp. 2898-2908, 2006.

[110] S. V. Dorozhkin, "Nanosized and nanocrystalline calcium orthophosphates," Acta Biomaterialia, vol. 6, no. 3, pp. 715-734, 2010.

[111] S. S. Banerjee, S. Tarafder, N. M. Davies, A. Bandyopadhyay, and $\mathrm{S}$. Bose, "Understanding the influence of $\mathrm{MgO}$ and $\mathrm{SrO}$ binary doping on the mechanical and biological properties of $\beta$-TCP ceramics," Acta Biomaterialia, vol. 6, no. 10, pp. 4167-4174, 2010.

[112] J. Wang and L. L. Shaw, "Nanocrystalline hydroxyapatite with simultaneous enhancements in hardness and toughness," Biomaterials, vol. 30, no. 34, pp. 6565-6572, 2009.

[113] Y.-P. Lu, Y.-M. Chen, S.-T. Li, and J.-H. Wang, "Surface nanocrystallization of hydroxyapatite coating," Acta Biomaterialia, vol. 4, no. 6, pp. 1865-1872, 2008.

[114] D. Xue, Y. Yun, M. J. Schulz, and V. Shanov, "Corrosion protection of biodegradable magnesium implants using anodization," Materials Science and Engineering C, vol. 31, no. 2, pp. 215-223, 2011.

[115] Y. Zhang, C. Yan, F. Wang, H. Lou, and C. Cao, "Study on the environmentally friendly anodizing of AZ91D magnesium alloy," Surface and Coatings Technology, vol. 161, no. 1, pp. 3643, 2002.

[116] H. Ardelean and I. Frteur P Marcus, "Corrosion protection of magnesium alloys by $\mathrm{Ce}, \mathrm{Zr}$ and $\mathrm{Nb}$ oxide layers," in Passivation of Metals and Semiconductors, and Properties of Thin Oxide Layers, P. Marcus and V. Maurice, Eds., Proceedings of the 9th International Symposium, Paris, France, July 2005, pp. 225-230, 2006.

[117] C. Ying-Liang, W. Hai-Lan, C. Hua et al., "Corrosion properties of AZ31 magnesium alloy and protective effects of chemical conversion layers and anodized coatings," Transactions of Nonferrous Metals Society of China, vol. 17, no. 3, pp. 502-508, 2007.

[118] S. Virtanen, "Biodegradable Mg and Mg alloys: corrosion and biocompatibility," Materials Science and Engineering B, vol. 176, no. 20, pp. 1600-1608, 2011.

[119] M. C. Turhan, R. P. Lynch, H. Jha, P. Schmuki, and S. Virtanen, "Anodic growth of self-ordered magnesium oxy-fluoride nanoporous/tubular layers on Mg alloy (WE43)," Electrochemistry Communications, vol. 12, no. 6, pp. 796-799, 2010.

[120] Y. Mizutani, S. J. Kim, R. Ichino, and M. Okido, "Anodizing of Mg alloys in alkaline solutions," Surface and Coatings Technology, vol. 169-170, pp. 143-146, 2003.

[121] A. L. Yerokhin, X. Nie, A. Leyland, A. Matthews, and S. J. Dowey, "Plasma electrolysis for surface engineering," Surface and Coatings Technology, vol. 122, no. 2-3, pp. 73-93, 1999.

[122] I. S. Park, Y. S. Jang, Y. K. Kim, M. H. Lee, J. M. Yoon, and T. S. Bae, "Surface characteristics of AZ91D alloy anodized with 
various conditions," Surface and Interface Analysis, vol. 40, no. 9, pp. 1270-1277, 2008.

[123] H.-Y. Hsiao and W.-T. Tsai, "Characterization of anodic films formed on AZ91D magnesium alloy," Surface and Coatings Technology, vol. 190, no. 2-3, pp. 299-308, 2005.

[124] S. Ono, M. Miyake, and H. Asoh, "Effects of formation voltage and electrolyte ions concentration on the structure and passivity of anodic films on magnesium," Journal of Japan Institute of Light Metals, vol. 54, no. 11, pp. 544-550, 2004.

[125] S. Ono, H. Kijima, and N. Masuko, "Microstructure and voltagecurrent characteristics of anodic films formed on magnesium in fluoride electrolytes," Journal of Japan Institute of Light Metals, vol. 52, no. 3, pp. 115-121, 2002.

[126] L. L. Li, Y. L. Cheng, H. M. Wang, and Z. Zhang, "Anodization of AZ91 magnesium alloy in alkaline solution containing silicate and corrosion properties of anodized films," Transactions of Nonferrous Metals Society of China, vol. 18, pp. 722-727, 2008.

[127] O. Khaselev and J. Yahalom, "The anodic behavior of binary $\mathrm{Mg}-\mathrm{Al}$ alloys in $\mathrm{KOH}$-aluminate solutions," Corrosion Science, vol. 40, no. 7, pp. 1149-1160, 1998.

[128] Y. Zhang, C. Yan, F. Wang, and W. Li, "Electrochemical behavior of anodized $\mathrm{Mg}$ alloy AZ91D in chloride containing aqueous solution," Corrosion Science, vol. 47, no. 11, pp. 2816-2831, 2005.

[129] H. Fukuda and Y. Matsumoto, "Formation of Ti-Si composite oxide films on $\mathrm{Mg}-\mathrm{Al}-\mathrm{Zn}$ alloy by electrophoretic deposition and anodization," Electrochimica Acta, vol. 50, no. 27, pp. 53295333, 2005.

[130] H.-Y. Hsiao, H.-C. Tsung, and W.-T. Tsai, "Anodization of AZ91D magnesium alloy in silicate-containing electrolytes," Surface and Coatings Technology, vol. 199, no. 2-3, pp. 127-134, 2005.

[131] S. Verdier, M. Boinet, S. Maximovitch, and F. Dalard, "Formation, structure and composition of anodic films on AM60 magnesium alloy obtained by DC plasma anodising," Corrosion Science, vol. 47, no. 6, pp. 1429-1444, 2005.

[132] H. Fukuda and Y. Matsumoto, "Effects of $\mathrm{Na}_{2} \mathrm{SiO}_{3}$ on anodization of Mg-Al-Zn alloy in $3 \mathrm{M} \mathrm{KOH}$ solution," Corrosion Science, vol. 46, no. 9, pp. 2135-2142, 2004.

[133] J. G. Brunner, R. Hahn, J. Kunze, and S. Virtanen, "Porosity tailored growth of black anodic layers on magnesium in an organic electrolyte," Journal of the Electrochemical Society, vol. 156, no. 2, pp. C62-C66, 2009.

[134] A. Ghicav and P. Schmuki, "Self-ordering electrochemistry: a review on growth and functionality of $\mathrm{TiO}_{2}$ nanotubes and other self-aligned $\mathrm{MO}_{x}$ structures," Chemical Communications, vol. 20, pp. 2791-2808, 2009.

[135] J. W. Diggle, T. C. Downie, and C. W. Goulding, "Anodic oxide films on aluminum," Chemical Reviews, vol. 69, no. 3, pp. 365$405,1969$.

[136] H. Masuda and K. Fukuda, "Ordered metal nanohole arrays made by a two-step replication of honeycomb structures of anodic alumina," Science, vol. 268, no. 5216, pp. 1466-1468, 1995.

[137] I. Sieber, B. Kannan, and P. Schmuki, "Self-assembled porous tantalum oxide prepared in $\mathrm{H}_{2} \mathrm{SO}_{4} / \mathrm{HF}$ electrolytes," Electrochemical and Solid-State Letters, vol. 8, no. 3, pp. J10-J12, 2005.

[138] H. Tsuchiya, J. M. MacAk, A. Ghicov, L. Taveira, and P. Schmuki, "Self-organized porous $\mathrm{TiO}_{2}$ and $\mathrm{ZrO}_{2}$ produced by anodization," Corrosion Science, vol. 47, no. 12, pp. 3324-3335, 2005.
[139] H. Tsuchiya, J. M. Macak, I. Sieber, and P. Schmuki, "Selforganized high-aspect-ratio nanoporous zirconium oxides prepared by electrochemical anodization," Small, vol. 1, no. 7, pp. 722-725, 2005.

[140] S. Ono, T. Nogasaka, H. Shimazaki, and H. Asoh, in Proceedings of the 206th Meeting of the Electrochemical Society, Meeting abstract, p. 788, Honolulu, Hawaii, USA, October 2004.

[141] I. Sieber, H. Hildebrand, A. Friedrich, and P. Schmuki, "Formation of self-organized niobium porous oxide on niobium," Electrochemistry Communications, vol. 7, no. 1, pp. 97-100, 2005.

[142] V. Zwilling, E. Darque-Ceretti, A. Boutry-Forveille, D. David, M. Y. Perrin, and M. Aucouturier, "Structure and physicochemistry of anodic oxide films on titanium and TA6V alloy," Surface and Interface Analysis, vol. 27, no. 7, pp. 629-637, 1999.

[143] J. M. Macak, H. Tsuchiya, and P. Schmuki, "High-aspectratio $\mathrm{TiO}_{2}$ nanotubes by anodization of titanium," Angewandte Chemie International Edition, vol. 44, pp. 2100-2102, 2005.

[144] J. M. Macak, H. Tsuchiya, L. Taveira, S. Aldabergerova, and P. Schmuki, "Smooth anodic $\mathrm{TiO}_{2}$ nanotubes," Angewandte Chemie International Edition, vol. 44, no. 45, pp. 7463-7465, 2005.

[145] H. Tsuchiya and P. Schmuki, "Self-organized high aspect ratio porous hafnium oxide prepared by electrochemical anodization," Electrochemistry Communications, vol. 7, no. 1, pp. 49-52, 2005.

[146] H. Asoh and S. Ono, "Anodizing of magnesium in amineethylene glycol electrolyte," Materials Science Forum, vol. 419422, pp. 957-962, 2003.

[147] J. Park, S. Bauer, K. Von Der Mark, and P. Schmuki, "Nanosize and vitality: $\mathrm{TiO}_{2}$ nanotube diameter directs cell fate," Nano Letters, vol. 7, no. 6, pp. 1686-1691, 2007.

[148] H. Tsuchiya, J. M. Macak, L. Müller et al., "Hydroxyapatite growth on anodic $\mathrm{TiO}_{2}$ nanotubes," Journal of Biomedical Materials Research A, vol. 77, no. 3, pp. 534-541, 2006.

[149] Y. C. Xin, J. Jiang, K. F. Huo, G. Y. Tang, X. B. Tian, and P. K. Chu, "Corrosion resistance and cytocompatibility of biodegradable surgical magnesium alloy coated with hydrogenated amorphous silicon," Journal of Biomedical Materials Research A, vol. 89, pp. 717-726, 2009.

[150] X. N. Gu, W. Zheng, Y. Cheng, and Y. F. Zheng, "A study on alkaline heat treated $\mathrm{Mg}$-Ca alloy for the control of the biocorrosion rate," Acta Biomaterialia, vol. 5, no. 7, pp. 2790-2799, 2009.

[151] Y. Al-Abdullat, S. Tsutsumi, N. Nakajima, M. Ohta, H. Kuwahara, and K. Ikeuchi, "Surface modification of magnesium by $\mathrm{NaHCO}_{3}$ and corrosion behavior in Hank's solution for new biomaterial applications," Materials Transactions, vol. 42, no. 8, pp. 1777-1780, 2001.

[152] K. Y. Chiu, M. H. Wong, F. T. Cheng, and H. C. Man, "Characterization and corrosion studies of fluoride conversion coating on degradable Mg implants," Surface and Coatings Technology, vol. 202, no. 3, pp. 590-598, 2007.

[153] T. Yan, L. Tan, D. Xiong, X. Liu, B. Zhang, and K. Yang, "Fluoride treatment and in vitro corrosion behavior of an AZ31B magnesium alloy," Materials Science and Engineering C, vol. 30, no. 5, pp. 740-748, 2010.

[154] A. Drynda, T. Hassel, R. Hoehn, A. Perz, F.-W. Bach, and M. Peuster, "Development and biocompatibility of a novel corrodible fluoride-coated magnesium-calcium alloy with improved degradation kinetics and adequate mechanical properties for cardiovascular applications," Journal of Biomedical Materials Research A, vol. 93, no. 2, pp. 763-775, 2010. 
[155] M. D. Pereda, C. Alonso, L. Burgos-Asperilla et al., "Corrosion inhibition of powder metallurgy Mg by fluoride treatments," Acta Biomaterialia, vol. 6, no. 5, pp. 1772-1782, 2010.

[156] F. Witte, J. Fischer, J. Nellesen et al., "In vivo corrosion and corrosion protection of magnesium alloy LAE442," Acta Biomaterialia, vol. 6, no. 5, pp. 1792-1799, 2010.

[157] X. Y. Ye, M.-F. Chen, C. You, and D.-B. Liu, “The influence of HF treatment on corrosion resistance and in vitro biocompatibility of Mg-Zn-Zr alloy," Frontiers of Materials Science in China, vol. 4, pp. 132-138, 2010.

[158] J. E. Gray-Munro, C. Seguin, and M. Strong, "Influence of surface modification on the in vitro corrosion rate of magnesium alloy AZ31," Journal of Biomedical Materials Research A, vol. 91, pp. 221-230, 2009.

[159] H. M. Wong, K. W. K. Yeung, K. O. Lam et al., "A biodegradable polymer-based coating to control the performance of magnesium alloy orthopaedic implants," Biomaterials, vol. 31, no. 8, pp. 2084-2096, 2010.

[160] X. N. Gu, Y. F. Zheng, Q. X. Lan et al., "Surface modification of an Mg-1Ca alloy to slow down its biocorrosion by chitosan," Biomedical Materials, vol. 4, Article ID 044109, 2009.

[161] K. Bleek and A. Taubert, "New developments in polymer-controlled, bioinspired calcium phosphate mineralization from aqueous solution," Acta Biomaterialia, vol. 9, pp. 6283-6321, 2013.

[162] J. Zhang, C. Dai, J. Wei, Z. Wen, S. Zhang, and C. Chen, "Degradable behavior and bioactivity of micro-arc oxidized AZ91D Mg alloy with calcium phosphate/chitosan composite coating in m-SBF," Colloids and Surfaces B, vol. 111, pp. 179-187, 2013.

[163] J. Zhao, X. Lu, and J. Weng, "Macroporous Ti-based composite scaffold prepared by polymer impregnating method with calcium phosphate coatings," Materials Letters, vol. 62, no. 17-18, pp. 2921-2924, 2008.

[164] A. Scott and J. E. Gray-Munro, "The surface chemistry of 3mercaptopropyltrimethoxysilane films deposited on magnesium alloy AZ91," Thin Solid Films, vol. 517, no. 24, pp. 68096816, 2009.

[165] A. F. Scott, J. E. Gray-Munro, and J. L. Shepherd, "Influence of coating bath chemistry on the deposition of 3-mercaptopropyl trimethoxysilane films deposited on magnesium alloy," Journal of Colloid and Interface Science, vol. 343, no. 2, pp. 474-483, 2010.

[166] M. S. Killian, V. Wagener, P. Schmuki, and S. Virtanen, "Functionalization of metallic magnesium with protein layers via linker molecules," Langmuir, vol. 26, no. 14, pp. 12044-12048, 2010.

[167] L. H. Chiu, C. C. Chen, and C. F. Yang, "Improvement of corrosion properties in an aluminum-sprayed AZ31 magnesium alloy by a post-hot pressing and anodizing treatment," Surface and Coatings Technology, vol. 191, pp. 181-187, 2005.

[168] W. Mertz, “The essential trace elements," Science, vol. 213, no. 4514, pp. 1332-1338, 1981.

[169] C. Palmer and S. H. Wolfe, "Position of the American Dietetic Association: the impact of fluoride on health," Journal of the American Dietetic Association, vol. 105, pp. 1620-1628, 2005.

[170] T. P. Rucdi and W. M. Murphy, Principle of Fracture Management, AO Publishing, Dupendorf, Switzerland, 2002.

[171] S. T. Xu, B. F. Ge, and Y. K. Xu, Pratical Orthopaedic, Military Medical Press, Beijing, China, 3rd edition, 2005.
[172] A. W. Lloyd, "Interfacial bioengineering to enhance surface biocompatibility," Medical Device Technology, vol. 13, no. 1, pp. 18-21, 2002.

[173] N. Winzer, A. Atrens, G. Song et al., "A critical review of the Stress Corrosion Cracking (SCC) of magnesium alloys," Advanced Engineering Materials, vol. 7, no. 8, pp. 659-693, 2005.

[174] N. Winzer, A. Atrens, W. Dietzel, V. S. Raja, G. Song, and K. U. Kainer, "Characterisation of stress corrosion cracking (SCC) of Mg-Al alloys," Materials Science and Engineering A, vol. 488, no. 1-2, pp. 339-351, 2008. 

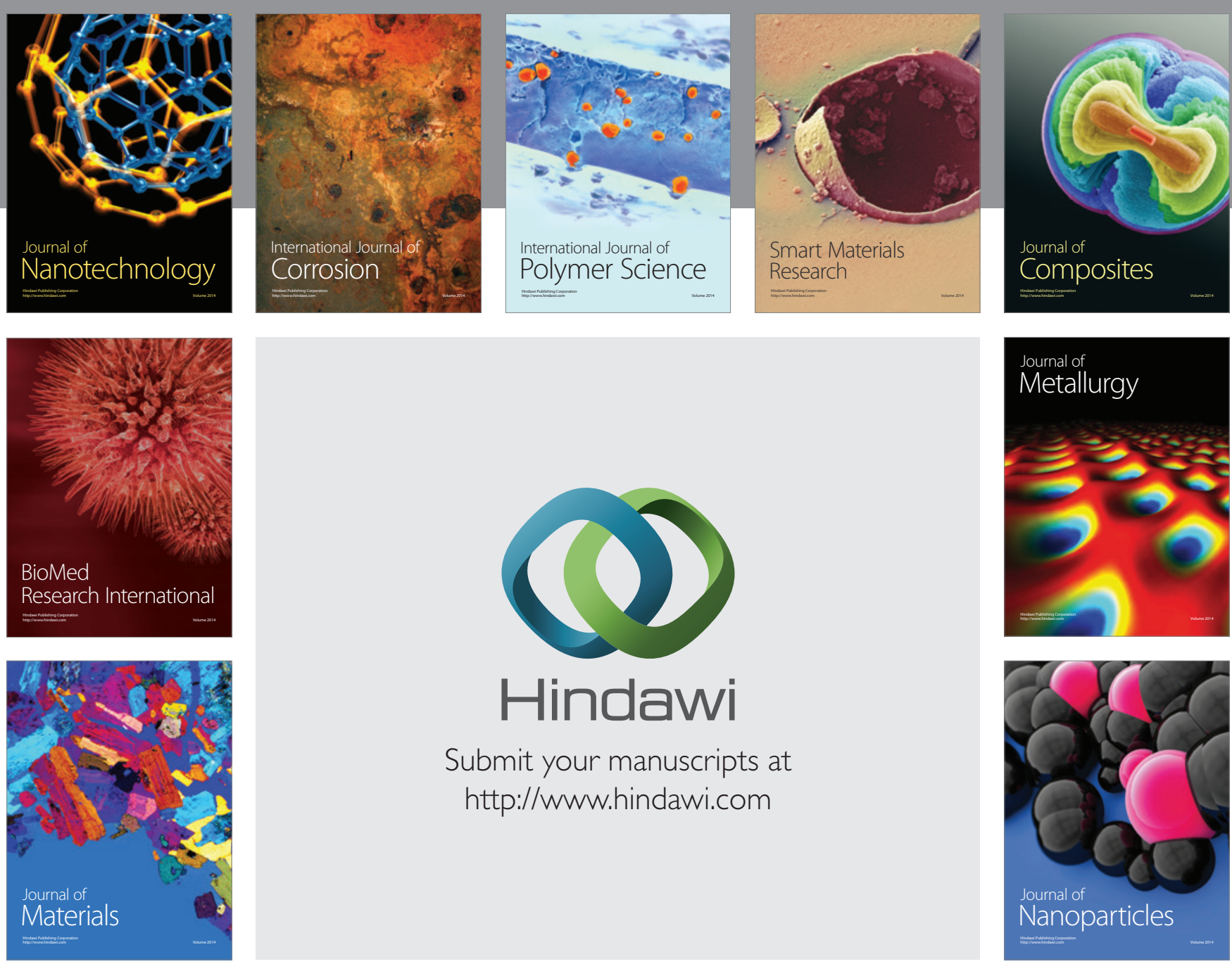

Submit your manuscripts at http://www.hindawi.com
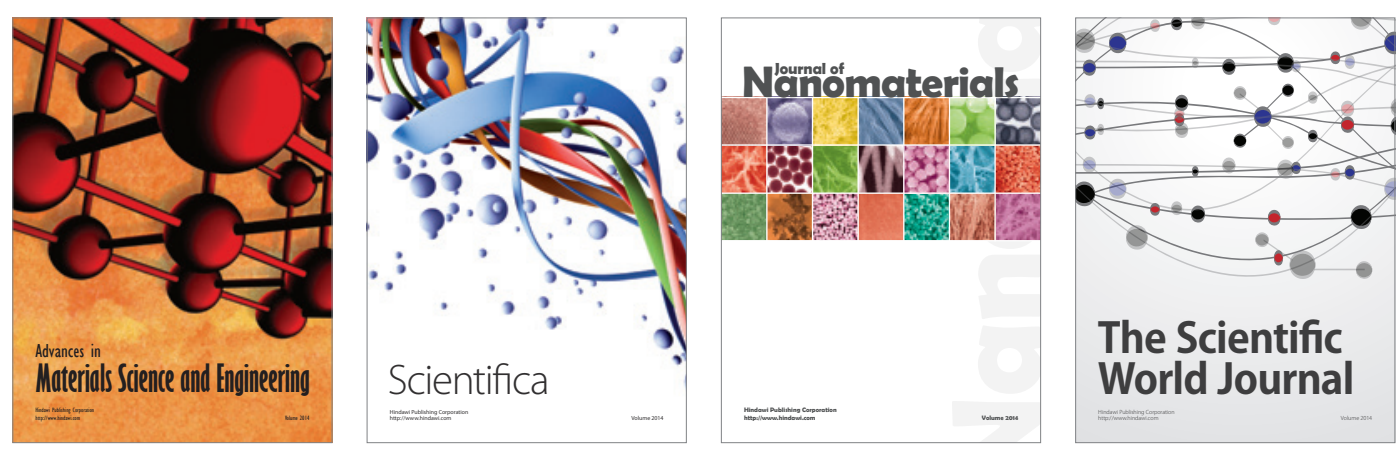

\section{The Scientific World Journal}
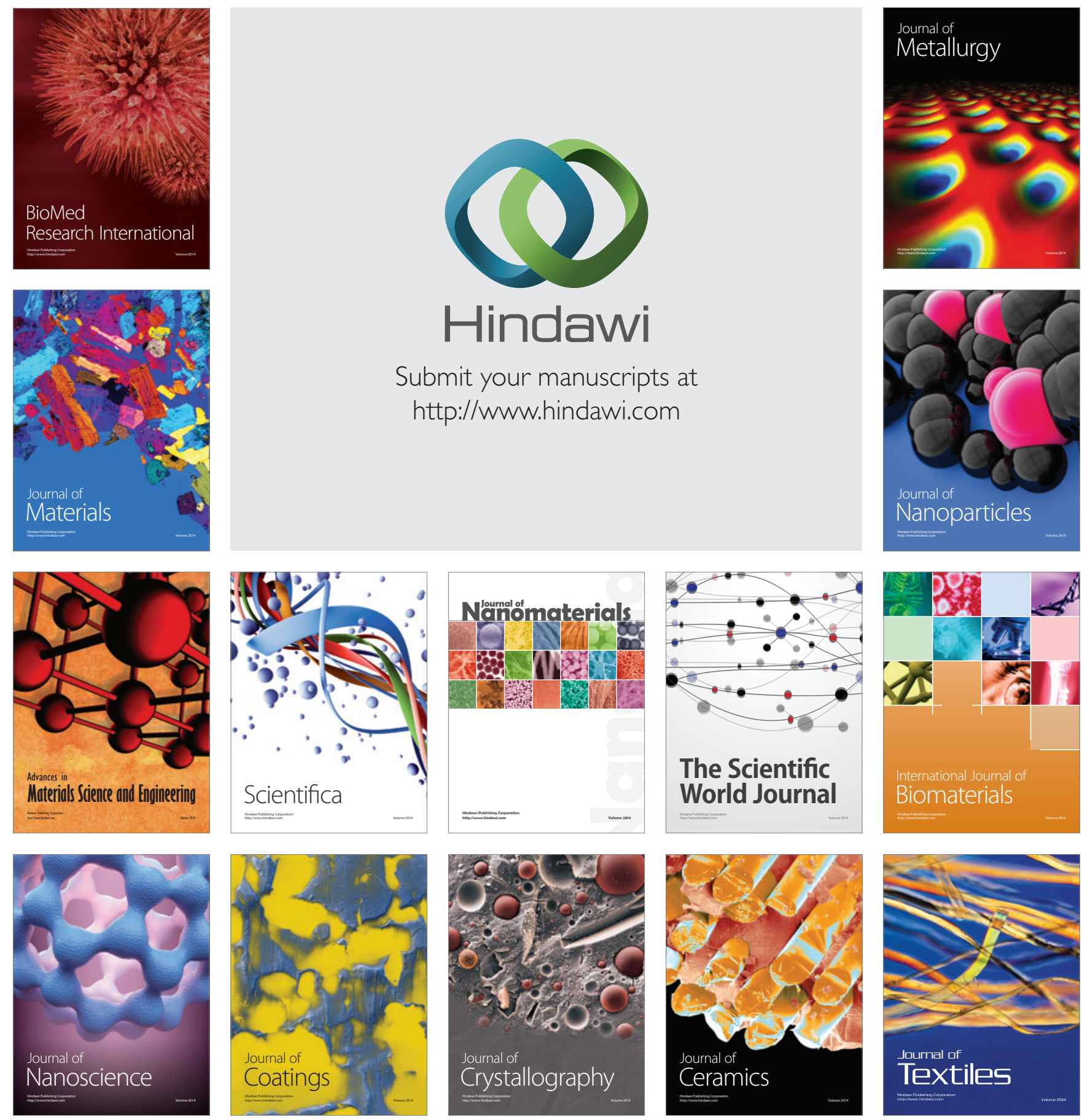